\title{
THE "GENERAL NOTES" COLUMN
}

To the Editor of the Journal:

Many members of the American Society of Mammalogists have signified their interest in the work of the Committee on Life-Histories, while those professing an interest in the work of the other committees are so far few in number. The reasons for this are perfectly obvious. The study of specimens, bones, and books is interesting; but the study of the living animal is even more interesting. It is perhaps not strange that because it is possible for persons without special training to acquire an interest in socalled popular natural history and because superficial and inaccurate observations have sometimes become current there has arisen in some quarters a prejudice against popular science.

Robert Ridgway once wrote "There are two essentially different kinds of ornithology: systematic or scientific, and popular. The former deals with the structure and classification of birds, their synonymies and technical descriptions. The latter treats of their habits, songs, nesting, and other facts pertaining to their life-histories" (The Birds of North and Middle America, Bull. 50, U. S. Nat. Mus., Part 1, 1901, p. 1). To the mind of the writer this distinction is a mistaken one. Is not the study of habits exactly as scientific as the study of structure? Structure acquires significance only as some habit is associated with it. It is, moreover, still an open question whether structure arose before habit, or habit before structure. Is not the distinction rather between the true and accurate and the false and inaccurate, whether one studies structure or habits, than between the scientific and popular? There is nothing inherently scientific about studies of specimens, bones, and books; nor anything inherently unscientific in studies of habits and life-histories. The scientific method can be applied as readily to the one as to the other.

I was impressed with your statement in the last number of this Journal that "Papers of general interest on life-histories, distribution, and habits are particularly needed, in order that the Journal may not be overbalanced with purely technical matter." With this proposition it is believed all readers of the Journal will be in agreement.

A tendency far too common among observers of wild life is to minimize the importance of their studies of habits. The dearth of information concerning the life-histories of some of our commonest mammals is amazing. It is consequently urged that papers and general notes in this province be submitted for publication. In particular the column of General Notes should become one of the most popular and best supported departments of the Journal.

It should be remembered that any sincere student with an enthusiasm for closer acquaintance with wild life can well become active in this field. "No human being and no book, but nature herself, is the supreme authority in natural history. The beginner may make as important an observation as the veteran investigator. The efforts of all are needed if our fund of information is in any sense to be complete" (Dept. Circular 50, U. S. Dept. of Agriculture, p. 4).

Walter P. Taylor. 


\section{$2 \mathrm{BHL}$ Biodiversity Heritage Library}

Taylor, Walter P. 1920. "The "General Notes" Column." Journal of mammalogy 1, 106-106. https://doi.org/10.2307/1373753.

View This Item Online: https://www.biodiversitylibrary.org/item/220052

DOI: https://doi.org/10.2307/1373753

Permalink: https://www.biodiversitylibrary.org/partpdf/90494

\section{Holding Institution}

Smithsonian Libraries

\section{Sponsored by}

Biodiversity Heritage Library

\section{Copyright \& Reuse}

Copyright Status: Not in copyright. The BHL knows of no copyright restrictions on this item.

This document was created from content at the Biodiversity Heritage Library, the world's largest open access digital library for biodiversity literature and archives. Visit BHL at https://www.biodiversitylibrary.org. 